Vol. $7, n^{\circ} 1 \mid 2003$

Varia

\title{
Self-Policing and the Policing of the Self: Violence, Protection and the Civilizing Bargain in Britain
}

\section{J. Carter Wood}

\section{(2) OpenEdition}

\section{Journals}

Electronic version

URL: https://journals.openedition.org/chs/614

DOI: $10.4000 /$ chs. 614

ISSN: 1663-4837

Publisher

Librairie Droz

Printed version

Date of publication: 1 July 2003

Number of pages: $109-128$

ISBN: 2-600-00865-9

ISSN: $1422-0857$

\section{Electronic reference}

J. Carter Wood, "Self-Policing and the Policing of the Self: Violence, Protection and the Civilizing Bargain in Britain", Crime, Histoire \& Sociétés / Crime, History \& Societies [Online], Vol. 7, n 1 | 2003 ,

Online since 25 February 2009, connection on 23 March 2022. URL: http://journals.openedition.org/ chs/614; DOl: https://doi.org/10.4000/chs.614

This text was automatically generated on 23 March 2022.

(c) Droz 


\title{
Self-Policing and the Policing of the Self: Violence, Protection and the Civilizing Bargain in Britain
}

\author{
J. Carter Wood
}

1 Recent years have seen much debate in Britain ${ }^{2}$ about the effectiveness and role of its police forces. Alongside investigations into institutionalized racism and sexism has come a different kind of criticism concerning police capabilities. Questioning of the role and competency of the police in controlling crime has become prevalent at various levels in British society. In 1995, Elizabeth Stanko summarized some results of the growing skepticism regarding the police:

Over the past few years, there has been a renewed interest in policing outside the uniformed police: the focus on vigilantes, the growth of the private security industry, the lack of confidence in the criminal justice system to mete out justice, public demands for longer, harsher prison sentences, and fear of no-go areas and young male renegades controlling neighbourhoods even police fear to tread all question the ability of uniformed police to control the policing enterprise ${ }^{3}$.

Concurrent with the periodic condemnation for using too much force (for instance in stifling protest or assaulting minorities) have arisen complaints from certain groups about the police's failure to go far enough in using their powers. For instance, as Stanko notes, feminists have reproved the police for failing to intervene sufficiently in domestic violence cases (or even for failing to "prevent» violence against women in the home). Furthermore, various communities - whether poor, minority and/or rural critique the police for failing to provide what is their assumed raison d'être: protection.

Since Stanko's commentary, scattered evidence of widening cracks in the policing model has become ever-more apparent. For instance, vigilantism, although exceedingly difficult to quantify, has loomed large in several well-publicized cases including the «anti-pedophile» riots around Portsmouth and elsewhere and the case of Tony Martin, a Norfolk farmer convicted of murder for the shooting of a teenage burglar. Those incidents had many distinct origins, but are linked by a consistent narrative that contributed to and followed them, namely, that of the failure of police protection. 
Among the most commonly expressed motivations by the crowds that harassed and assaulted suspected pedophiles was a lack of faith in the police to sufficiently safeguard their children ${ }^{4}$. The Martin case provoked heated public discussion from many sources (including the leadership of the Conservative Party) regarding police ineffectiveness in fighting rural crime and the legitimacy of force on the part of homeowners ${ }^{5}$. More recently, in December 2001 the Home Secretary, as part of policing reforms designed to respond to such criticisms, unveiled proposals for the deployment of thousands of civilian wardens - possibly with the power to use «reasonable force» - on the streets of British cities ${ }^{6}$.

4 The contours of the present police debate are not new: they have long been closely tied to the institutional and ideological histories of professionalized policing. The police, furthermore, emerged and have developed in interaction with changing mentalities of violence ${ }^{7}$. State policing institutions have always had an ambiguous relationship to the public, at times verging into outright hostility; yet, the nature of the policing enterprise itself is also problematic. In various ways, histories of British crime tend to emphasize the ways that pre-nineteenth-century Britain was an un-policed or at the least a lightly policed society. However, those characterizations are accurate only if «policing» is taken to be synonymous with «the police». Even though British communities before the nineteenth century were not subject to the kind of professionalized supervision now commonplace, they were in fact highly «policed» through means very different from those that would later become the standard of «law and order». While not independent of government influence, day-to-day social relations (including crime and dispute settlement) in early-modern society were largely «self-policed». Order was, in most cases, maintained through a distribution of violence legitimated by a «customary» mentality that organized retributive, autonomous and disciplinary violence ${ }^{8}$. From neighborly «rough music» to direct interpersonal assaults, customary violence marked and defended the boundaries of acceptable behavior and enforced conformity to community standards (or individual interpretations of those standards).

5 The narrowing of the boundaries of legitimate violence and attempts to translate traditional forms of community justice into institutional, state processes were essential parts of the nineteenth-century civilizing offensive. The "state», as Weber famously defines it, has a monopoly on violence ${ }^{9}$. Historically analyzed, the claiming by states of a monopoly on the legitimate use of force is one of the engines of Norbert Elias's "civilizing process $»^{10}$. The emphasis here should clearly be placed on the claiming of that right, as it has frequently been contested in theory and resisted in practice. The transferal of dispute settlement and community protection into the powers of the British state was, after all, a drawn-out and tentative undertaking. Undoubtedly, this civilizing project - bringing processes into official channels that had customarily belonged to a much more diffuse economy of legitimate violence - has had great successes. What is perhaps remarkable is the relatively rapid victory of this «civilizing bargain»- markedly strict limitation of individual aggression in exchange for state maintenance of pacified social spheres and provision of official channels for the protection of individuals and their property - across a broad spectrum of society. State policing has been central to that establishment, and by the end of the nineteenth century the widespread hostility of the public (particularly that of working-class communities) to the police was, by-and-large, replaced by acceptance of the legitimate place of the policeman in British society. It is undoubtedly true that that «acceptance» 
was based on a variety of myths, varied according to various social factors, and remains conflicted and highly conditional. However, even among most critics of the police, the core concept of state policing remains largely unquestioned. In fact, the «policing idea» may have been too successful for its own good: many campaigners against various police failings seek the improvement of the policing model - based upon increasing expectations of personal safety - rather than facing the capabilities, limitations and history of that model itself.

6 Nearly two centuries of state policing have been inevitably connected to shifts in British culture, particularly attitudes toward violence and the notions of community autonomy, discipline and retribution that underlay them. However, contemporary policing difficulties also point to tensions, countervailing trends and the incomplete nature of that cultural re-contouring. What follows is an attempt to add to the conceptual debate about the transition to a police-society through a focus on the history of mentalities of violence. I will focus first on some aspects of the history of «self-policing» by individuals and communities in the early nineteenth century. Second, I will consider the development of new models of policing, partly through the expansion of institutionalized policing, but more directly on the related issue of an increasing "policing of the self.» The relationship between self-policing and the policing of the self is one of continuity as well as change, coexistence as well as conflict; one was not simply replaced by the other, even though by the end of the nineteenth century overt resistance to the police was largely confined to socially marginalized groups. Finally, I will briefly consider these issues in relation to the concept of a «civilizing bargain» suggesting that to some extent the current tensions within present-day policing are evidence of built-in conflicts within the model of social change suggested by Elias.

\section{Self-Policing}

7 Many things flavored nineteenth-century British culture, but custom was among its most important ingredients, particularly regarding attitudes toward violence. Customary culture developed a strong predisposition for the autonomous ordering of community life and the settling of disputes outside of the legal procedures that had become common among the middle and upper classes by the late seventeenth century. Unlike increasingly «refined» attitudes toward violence - rooted in the eighteenthcentury "culture of sensibility» and emerging in the nineteenth-century «invention» ${ }^{11}$ of violence as a social problem - physical aggression had a widespread legitimacy at the center of community life ${ }^{12}$.As a culture of «civilizing» refinement developed, customary culture - although once shared across social ranks - became increasingly confined to (and identified with) the working classes. The location of violence within a community context is key to understanding the customary mentality of violence and its dominant characteristics: retribution, autonomy and the maintenance of social norms through disciplinary force or its threat.

The British customary mentality, while separate from the Mediterranean culture of the vendetta, legitimated the use of violence to settle disputes or to punish deviants, and there was little questioning of the biblical notion of an eye for an eye ${ }^{13}$. Popular belief in violent retribution was a powerful motivation for some forms of working-class 
violence, whether at work, at home or in the wider community. In 1839, an observer of the industrializing northern towns wrote:

The notion that justice is only legalized revenge, and that every crime must be atoned for by a certain amount of physical suffering, prevails so universally that it may almost be said to have passed into an article of faith. Never was there a more mischievous delusion ${ }^{14}$.

9 The retributive notion of justice was, of course, a «delusion» that had been shared and imparted - by the state, and, despite some writers' misgivings, it remained a significant if far less central feature of British punishment. More «refined» discourses of humanitarianism were never entirely successful in purging middle-class thought and state policy of customary elements, suggesting the significance of «resistant mentalities» and bourgeois «alibis» for aggression while highlighting the power of a customary counternarrative to that of sensitized «progress» ${ }^{15}$. The cultural lessons learned over centuries at the foot of the scaffold and pillory and lived throughout communities were difficult- and in the absence of an alternative, perhaps impractical - to shed.

Customary vengeance took a more direct, immediate and personal form than the retribution advocated by the state - particularly as the secondary punishments of penal transportation and imprisonment developed - and represented a «world of 'justice' outside the official courts» ${ }^{16}$. Such «infrajudicial» methods of dispute settlement were widespread and persistent in early-modern European societies ${ }^{17}$. Beyond the individual level, the devices available to communities to impose their will through force, from largely symbolic «rough music» to more extreme forms of violent intervention, were numerous. Over the nineteenth-century, such «extra-legal» violence came under increasing state observation and sanction. However, «extra-legal» is itself a moving definition, and the boundary that marked it was both flexible and permeable. It was flexible because the law of violence underwent marked shifts in the early nineteenth century and interacted in practice with a more complicated «unwritten law» of customary popular culture ${ }^{18}$. It was permeable because of the traditional interplay between legal authority and popular violence. Before the creation and spread of a professionalized police force in the first half of the nineteenth century, victims of crime typically had to apprehend the accused perpetrators on their own, only occasionally with the assistance of a local part-time and unpaid constable ${ }^{19}$. Punishments such as the pillory, used into the nineteenth century, extended the ambiguities of «extra-legal» violence further, tolerating, sometimes expecting, an additional measure of «popular justice» to mingle with the power of the state to punish offenders. On the other side of "permeability", popular justice might at times mingle extra-legal violence with mimetic usage of the forms of state law $^{20}$.

11 Regarding the concept of "protection» and taking Elias's theories into account, it seems clear that under the customary mentality one expected to encounter violence with some regularity - that it was, to some degree, «normal» - but that one, whether alone or in a group, was more legitimately entitled to use violence in response. As I will discuss in the next section, an essential part of the state reform project of the nineteenth century was the reversal of this situation. However, in the relative absence of institutionalized state policing forces, the legitimacy to use violence was diffuse: customary mentalities provided both justification for and strategies of violence to promote «justice», maintain social order and deal with crime. Early-modern communities and individuals resorted to violence - under the customary mentality, 
legitimately - to protect a range of «psychic property». According to Malcolm Greenshields, "psychic property» includes all a person possesses mentally or physically that can be violated, such as «honor dignity, space, possessions, and the physical person ${ }^{21}$. This definition usefully connects the material and immaterial, the instrumental and symbolic, and the performative and practical elements of earlymodern violence, highlighting the way that such violence was at the heart of community relations and the broad range of «properties» that self-policing was organized to protect.

These customary imperatives and methods persisted long into the nineteenth century, even as they came under sustained pressure from the state and refined culture. A few specific contexts of customary self-policing can be pointed to as signal examples. Physically assaulting robbers, even to the point of death, could be justified under this customary violence code and even winked at by state authorities in early stages of the transition to an institutionalized policing model ${ }^{22}$. Violent treatment of thieves and shoplifters was also a legitimate part of customary self-policing, as described by Henry Mayhew $^{23}$. Such vigilante-style acts were common and accepted by the general community, including some thieves themselves. In Shropshire in 1836, the occupier of a home caught a burglar in the act. A constable was not immediately available. People gathered around, and «someone said: 'Give him a good thrashing and let him go.' [The burglar] asked Reeves [the occupier] if he would be satisfied with that, but Reeves said no ${ }^{24}$. In that instance, the occupier was not satisfied with personal vengeance; however, apparently his neighbors - and the thief - would have seen such a settlement as legitimate. Such self-help could lose legitimacy if excessive force was employed; however, there was a tendency to accept the use of violence to defend property, including working-class property ${ }^{25}$.

13 Another expression of this underlying imperative was the existence of a well-defined and popular form of popular dispute settlement: the ritualized street fight. «To say that labouring men", asserted a defense of pugilism,

like their betters, should always appeal to the laws when they quarrel, is rank hypocrisy and an insult to common sense. They have neither time nor money to offer in sacrifices for the protection of our Courts of Law and Equity, such as they are: they must settle the quarrels amongst themselves as well as they can; and out of this necessity have sprung up boxing and the laws of the ring ${ }^{26}$.

British men, primarily laborers, were renowned for fist fighting according to certain rules of fairness. These involved fighting in rough "rings», according to «rounds» and having «seconds» present, along with various rules on «fair» and «foul» blows ${ }^{27}$. The «laws of the ring» were adapted far outside the contexts of sport and were a crucial part of working-class masculine life. Working-class violence among men was often impulsive: disputes could quickly lead to blows. However, these confrontations were often confined into ritualized forms that channeled retribution into more predictable forms. Once passions had cooled, there was often a desire not to further prosecute the matter, and reconciliation was often swift. In the absence of economic power (and therefore legal power) violence was a «resource» over which working people had direct control and built on customary traditions of self-help in settling their own disputes ${ }^{28}$.

Feelings against «interference» by authorities were strong, and violence was often organized to maintain community autonomy. The customary mentality was adapted to urban environments as the nineteenth century progressed, and the insularity of some groups and communities could be violently expressed. In 1828, a group of bookbinders 
were brought before the Guildhall police court accused of «having beaten and kicked sundry watchmen» after a watchman intervened in a dispute between one of them and a woman ${ }^{29}$. Andrew Mearns noted the hostility, and sometimes violence, that greeted missionary workers ${ }^{30}$. Writing of the Black Country, David Woods suggests that

communities were generally not well disposed to outside interference in their lives. Police, bailiffs, public health inspectors, School Board officials were all unwelcome visitors to the yards, courts and backstreets and were often met with hostile resistance ${ }^{31}$.

Most violence was intra-class and among people who knew each other well, and attacks on middle-class outsiders were relatively uncommon unless they were acting as representatives of an agency (whether state or private) perceived to be overly intrusive toward an individual's or neighborhood's autonomy. In times of exceptional tension, the reluctance to use violence outside of one's class could evaporate, as it did during some labor disputes ${ }^{32}$, periods of political upheaval or during crime panics ${ }^{33}$.

Behind these various signs of a vigorous culture of customary violence was a complex mechanism of maintaining community cohesion by dealing with perceived disruptions and transgressions through self-policing. However, there were different kinds of community violence. Conceptually, a useful approach comes from a study of a very different society and era. Steven C. Caton, in his recounting of an incident that grew into a short but sustained period of tribal violence in Yemen in 1980, distinguishes between "violence of community» and "violence of exclusion». "Violence of community», is a form of violence that «reconstitutes relations among parties.» When the Yemeni tribesmen of Caton's study believed a wrong had been committed,

It was not to the central state that the contending parties turned, or not usually, for the state, it was feared, would jeopardize the region's culturally valued sense of autonomy. Instead, they turned to each other, and would enter into a complex and delicate process of feuding and mediation in the hope of coming to a resolution of their differences ${ }^{34}$.

In seeking autonomous resolution, tears in the social fabric caused by disputes were repaired, and community authority was reassembled and strengthened. Just as there was a «violence of community» that sought to reconstitute social relations, there was a «violence of exclusion»:

By «violence of exclusion» I mean a violence that has the opposite aim [to that of violence of community], one of driving an opponent out of the community rather than trying to draw him back into it. This may be a violence of brute force, such as open warfare, or of dictat... but the intention is the same: the removal of the unwanted person or group from the shared space of the community ${ }^{35}$.

19 The concepts of community and exclusionary violence can be applied to British customary mentalities and were used by social groups to protect themselves from internal or external threats. Customary notions often shaped violence into limited forms: the ritual fistfight and types of «rough music» - violence of community - show how ritual and custom could be mobilized violently, but with restraint. Such restraint might be relaxed or ignored in response to «outsiders» or seriously threatening deviants: in those cases, more severe force - a violence of exclusion - would be deployed $^{36}$. The theme of «exclusion» can be developed further. As is well known, working-class communities became increasingly socially excluded in the nineteenth century; in large measure, that trend was a function of the middle classes' ability to separate themselves spatially and to secure the boundaries of their pacified spaces with the assistance of the police ${ }^{37}$. However, exclusion was not simply a property possessed 
by members of the refined social strata. Within working-class communities there were gradations and configurations of power, several overlapping layers of exclusion, and various excluded groups. Members of a community claimed the power to exclude others from their locality through violent means, a power upon which the state increasingly looked askance as it strove to monopolize legitimate physical force.

Autonomous self-policing was therefore a customary goal of British communities, andboth «violence of community» and «violence of exclusion» were important methods in managing social relations. While violence in the «customary» mindset was more accepted, such legitimacy depended upon adherence to community expectations as to the motivations for and extent of violence. In order to monitor its legitimacy, «customary» violence was often «located» - culturally and spatially - at the center of community life and surrounded by a code of assumptions as to its legitimate form. The use of violence to control public spaces and to exclude transgressive individuals from them was, in part, motivated by an assertion of the legitimacy of self-policing. For instance, a police officer recounting the community ire that would descend upon «bet welchers» (swindlers who would leave race tracks after taking bets and money) emphasized the typical self-policing mechanisms of a customary mentality still operative in the late nineteenth century. Some «welchers» were able to get away undetected. However,

sometimes there is a little hitch in the arrangements; his line of retreat is cut off, or a goodly number of his clients may have him under observation, and then, if he attempts to get away, the cry of «welcher» is raised, and the miscreant is likely to be almost torn limb from limb by the crowd. Not only is he attacked by those whom he is endeavouring to victimize, but a welcher is always considered "good sport» for all who can get near enough to let fly at him ${ }^{38}$.

21 Similarly, «informers» (and in labor disputes, «blacklegs»), like «welchers», were subject to an identifiable code of customary attitudes to, and shared vocabulary of, violence for dealing with violators of community standards through particular policing strategies. In the late nineteenth century, someone could still be «ducked» by his workmates as an informer and shirker ${ }^{39}$. Public spaces were seen as the legitimate sphere of community retribution, and retributive, autonomous violence of community and exclusion were the preferred means. Mobbing in the streets, calling out the crimes of suspects to attract a crowd and the resultant beatings and peltings were motivated by this customary mentality ${ }^{40}$. It is in part because these manifestations of custom were motivated by a challenge to official authority over the management of public space that they were viewed as so threatening by the police and the state ${ }^{41}$.

Depending upon specific circumstances, violence against deviants might be long lasting or brief. A short, limited attack might be made, and the transgressor then admitted back into the good graces of the community. Against «outsiders», however, or in times of increased tension (for example, during labor disputes) violence could be more sustained and serious. Motivated by a mentality that asserted the right of the community to police its own moral boundaries, community control was often enacted through a strategy of violence that excluded transgressors and limited their use of public spaces. Such violence could be either short and severe in the case of perceived serious threats, or of more constant but less severe punishment such as that meted out to local drunks or nuisances ${ }^{42}$.

23 Community self-policing, autonomous dispute settlement and the customary mentality of violence more generally played important roles in the maintenance of social 
relations and «order» in the eighteenth and nineteenth centuries. Such contexts, of course, interacted with a "control culture ${ }^{43}$ of official authority: the self-regulation of community life was deeply implicated in particular with local legal, economic and social hierarchies. Moreover, the contours of «custom» were themselves already shaped by «civilizing» pressures, and I do not suggest that ritualized forms of violence and community order were behaviors that had a timeless stability often suggested by the word "custom.» Custom itself was an adaptable and changeable discourse that interacted with a society in flux. However, in the nineteenth century, the growing power of the central state combined with the more diffuse impetus of new standards of behavior and self-restraint (of which Victorian «respectability» was an important part) were to increase sharply the disassociation of refined and customary mentalities. As part of the «civilizing offensive» the spectrum of «legitimate» violence and those who were authorized to wield it narrowed. At the same time, new discourses of refinement were adopted by broader sections of British society. I turn now to the series of changes that were set in motion as a result of these trends in regard to the imperatives of selfpolicing, authority, community autonomy and the elaboration of new standards of restrained interpersonal comportment that I gather under the rubric of the «policing of the self».

\section{The Policing of the Self}

With the growth of police forces through the nineteenth century, the state, as part of a wider reformative movement, gradually sought to limit «extra-legal» violence. These moves by the state singled out certain types of physical aggression that were redefined as «outside» the law and thereafter limited as part of an increasingly strident (and ever-more accepted) claim of a state monopoly of legitimate violence. «Extra-legal» was (and remains) a category marked by a moving boundary, one that was (and is) often contested. The monopolization of legitimate force and the creation of what Elias calls "pacified» public spaces was one of the key aims of state building in the nineteenth century ${ }^{44}$. Gradually, this began to influence wide swathes of British daily life, although the bias toward self-policing remained strong in working-class communities. Maintaining independence from authorities was a prime goal of workingclass life even while workers increasingly accepted legal means or appeals to the police to settle disputes, often tactically using new state-sanctioned methods to pursue a variety of traditional grievances ${ }^{45}$. However, commitment to community autonomy remained, and perhaps was strengthened, in response to police enforcement of a vast number of regulatory acts in the second half of the nineteenth century. The customary mentality of violent «self-help» contributed to a complicated relationship between working-class people and authority figures such as the police.

The innovations of Peel's police initiatives in the 1820s and their extension to the provinces in the 1850s were much remarked upon and originated in response to heightened fears about crime. The tradition of part-time, amateur and sometimes unpaid constables was neither appropriate to the increasing urbanization of British society nor well fitted to the imposing of new standards of propriety and pacified public spaces. In certain areas, the «old» police were seen to be utterly ineffective at stopping violent crime and controlling the streets. However, the historiography of policing often overstates both the ineptitude of traditional policing and the efficiency and power of the new ${ }^{46}$. Long after the introduction of modernized police forces, there 
were certain areas that were avoided by police, effectively ceding control of the streets to their inhabitants, and individual police officers were often willing not to interfere in certain violent situations ${ }^{47}$. Reminiscing about his early experiences as a policeman and detective in mid-century London, Timothy Cavanagh recalled that the police at times allowed street fights to continue, particularly if they involved several people. As one example, he noted a fight that ended as quickly as it began without any interference from a police officer who chose not to intervene ${ }^{48}$. Thus, while the police did often prevent violence, the intervention of a police officer might at other times be counterproductive to public «order», expanding the extent and duration of violent activity.

Policemen were often in a precarious position in the streets: their claim to authority could be quickly undermined if they were perceived to have overstepped community acceptance of their legitimate role. As Conley has noted, "peaceful coexistence [between the police and a community] depended on a clear understanding of local customs as well as the law $»^{49}$. The willingness of people to assault police officers, either to prevent their interference in a given incident or to rescue suspects, points to the contested nature of police authority ${ }^{50}$. Policemen often required the assistance of people in the street to make an arrest if a suspect became unruly or resisted apprehension $^{51}$. There were times when such help was readily available. At other times, some bystanders in the streets assisted the police while others resisted them. Such a mixture of contestation and acceptance was a feature throughout the nineteenth century; however, the boundaries of legitimate authority were often unclear and depended upon the individual circumstances of an incident and the character of the officer himself ${ }^{52}$.

Official efforts to clear the streets, in an attempt to create purified and pacified public spaces, were often highly resented. Such innovations as the «moving on» system, in which the police broke up congregations of men on the streets and in front of pubs, «brought the arm of municipal and state authority directly to bear upon key institutions of daily life in working-class neighborhoods», and the result was often resented and at times resisted ${ }^{53}$. Police interference in street disputes often forced a legal proceeding between the participants who were sometimes quickly reconciled between themselves, yet still faced the time and expense of a court case ${ }^{54}$. Police intervention represented an attempted imposition of a new, official authority over dispute settlement in conflict with the «customary» predilection for direct, autonomous action. Increasing deployment of state power in the form of the police and efforts to monopolize force caused resistance in working-class communities, the main target of new "policeman state» ${ }^{55}$. «Resistance» is a concept with many applicable interpretations. For example, V.A.C. Gatrell has asserted the significance of «resistant mentalities» in reference to ideas regarding death and capital punishment, emphasizing «resistances to change» and the power of «inertia» in attitudes toward hanging in particular and cultural attitudes more generally ${ }^{56}$. Resistance is thus conceptualized as a powerful, although largely passive, consequence of tradition. Michel de Certeau emphasizes a rather different, active form of resistance related to the use of urban spaces. Within a particular space, «Innumerable ways of playing and foiling the other's game, that is the space instituted by others, characterizes the subtle, stubborn, resistant activity of groups which, since they lack their own space, have to get along in a network of already established forces and representations» ${ }^{57}$. New forces arose, but did not sweep away the complex and deeply rooted traditions of community 
organization that had gone before. The customary self-policing described in the previous section functioned in this active way within the expanding reach of state policing.

Some sorts of violence, particularly violent exclusionary practices, were a type of resistance, asserting the authority to exclude members of the community and to selfpolice the boundaries of community standards (through an appeal to customary rights and legitimacy). Such practices can be seen to have resisted «civilized» hierarchies of authority. However, resistance may define a counter-narrative of power by not only creating alternative freedoms but also by imposing different inequalities and exclusions. Violence concerned not a single oppressive power, but multiple levels of exclusion, power and domination. As Foucault has noted,

power is not exercised simply as an obligation or a prohibition on those who «do not have it»; it invests them, is transmitted by them and through them; it exerts pressure upon them, just as they themselves, in their struggle against it, resist the grip it has on them ${ }^{58}$.

Resistance implied at least an assertion of independence from state authority and from «civilized» or «respectable» standards of behavior, while also claiming the power to impose an alternative order. There were preferred sites of resistance - mainly the streets and the other spaces of working-class social life - and there were also preferred representatives of the dominant power to be resisted. The most visible manifestation of new forms of state authority in the nineteenth century in the daily lives of workers were the police, and it is in relations with the police that an important aspect of resistance becomes visible.

There were many explicit disputes over the control of streets. There were particular points of dispute: for instance, Guy Fawkes celebrations were particularly tense,and as the police gradually increased their influence over daily street life, the commemoration became a date for challenges to authority and attempts to subvert police control of the streets ${ }^{59}$. Holidays, in line with customary notions of license, often led to disruption and challenges to official authority ${ }^{60}$ as did elections ${ }^{61}$. However, there were other, everyday contexts in which autonomous community power struggled with new forms of authority to maintain control. I have cited above the ways that thieves, local deviants and outsiders were handled. The expansion of police forces, the increasing role of police in taking matters before magistrates, and magistrates' increasing determination to bind over witnesses, prosecutors and defendants meant that official law more consistently drew out offences against the person into legal proceedings ${ }^{62}$.

31 For example, William Bridges and George Mead fought on a London street in $1834^{63}$ Mead was driving a cart laden with macaroni when he came upon an omnibus driven by Bridges. Because Mead was concerned that it would soon rain and damage his cargo, he was in a great rush. He wanted to pass Bridge's omnibus, but could not,

which so enraged him that he flew in a passion and took hold of the heads of the horses then being driven by your petitioner with one hand. His whip being in the other hand, the lash of it struck your petitioner [Bridges] which provoked him so much that he struck the said George Mead several times, who defended himself by striking again at your petitioner and a fight ensued which was of only two or three minutes duration.

They were quickly taken to a magistrate's office and Bridges was sentenced to nine months' imprisonment for the assault. However, Mead, the prosecutor, was the first signatory to Bridges's petition for mercy, and the petition notes that «the prosecutor 
considers the assault by no means of a serious character and he has written to your petitioner and also called on him in the prison and declared he will willingly lose a day or two's work or do anything in his power to get your petitioner's imprisonment shortened and has signed the petition for that purpose.» Among two men of humble means, the fight was a trifling matter, and had they not been hustled before a magistrate the case may not have gone to trial. The prosecutor appears not to have seen himself as a victim, and it is likely that he viewed the altercation as a «fair fight».

In spite of resistance and resentment, there was another side to working-class attitudes to the law. The «civilizing process» functions not only through imposition but also through the spread of new attitudes and standards of behavior: the transformation of external structures of control into internal inhibitions is one of the themes at the heart of Elias's writing ${ }^{64}$. Although there was great animosity between the working class and the police during the period of their first general introduction into British society, workers' attitudes later became more ambivalent. At times, popular reaction to the police could be actively supportive, particularly as the nineteenth century wore on and the presence of police became less of an innovative intrusion and more of an accepted fact of life. Working people frequently used or cooperated with the law, and this acceptance of legal proceedings gradually spread as informal, customary dispute settlement was superseded by formal, «civilized» legal participation, especially as the state made efforts to allow poorer plaintiffs to take part in law ${ }^{65}$.

As to the police, grudging respect and acceptance - likely dependent upon local contexts and the character of individual policemen - is apparent in some instances in the later Victorian period, the time when the figure of the «bobby» was taking fuller form. «When an officer does his duty without unnecessary harshness», John Paget, an observer of the police courts stated, «he is considered as an honourable enemy, to be feared and avoided, to be defeated by stratagem, or if need by force; but he excites no feeling of hatred or malignity; indeed he is not unfrequently appealed to by the man he has just captured to speak a good word on his behalf ${ }^{66}$. There were many occasions in which workers accepted and even assisted the police in their activities, assuming, of course, that those activities met with community approval. The complicated nature of popular relations with the police were commented upon by Paget in 1875:

When an officer arrests a prisoner in the very act of committing a felony, or steps in to quell a fray whilst the blood is hot, he not unfrequently gets roughly or even savagely handled...but when a criminal is arrested subsequently, a tap on the shoulder with «I want you, Jack», is generally quietly submitted to ${ }^{67}$.

Although it was a fairly optimistic view of policing, Paget's conclusions ring true for at least a significant portion of arrests. Suspects often gave themselves up with little struggle, even after committing brutal, impulsive violence, and many officers did, as Paget also noted, speak «a good word» on a criminal's behalf, either at trial or in petitions for mercy ${ }^{68}$. By the time he was writing, the police had reached a relatively stable acceptance in many working-class communities. The parliamentary Brutal Assaults Report, written in the same year, contains many references to the high number of assaults on the police, although authorities themselves understood that police «indiscretion» could at times be at the source of such attacks ${ }^{69}$. However, by the later nineteenth century, these attacks, though still frequent, became exceptions to the generally accepted presence of police forces. As one police historian has suggested of nineteenth-century London: 
Except among persistently antagonistic groups like the costermongers, the police did achieve at least a grumbling working-class acquiescence to their authority. By the 1860 s, there was more violence against them in the music halls than on the streets $^{70}$.

If the police interfered with strongly held customary ways of life (for example, by attempting to suppress popular customs, wakes and fairs) or crossed a popularly perceived line of fairness (as they did when they assisted employers and blacklegs during labor disputes, or violated what workers perceived as «rights»), or appeared to be ineffective in protecting the community, the imperatives of customary community violence could be activated.

It was only gradually, through a long process of tense negotiation, that working-class communities generally accepted police authority. However, by the late nineteenth century working-class Londoners were often willing to call upon police assistance ${ }^{71}$. By that point, there had been many decades of civilizing efforts and the increasing importance of respectability among the working class went hand-in-hand with increasing police «legitimacy.» Acceptance was, from its beginnings, highly contingent, selective and strategic. For instance, although working-class wives might call on the authorities for certain needs, such as separation orders and to have summonses enforced against husbands, they continued to concurrently «thwart» the police at any opportunity $^{72}$. Competing claims to the authority to use violence in the public sphere and to control of the streets and became less intense, but they were never entirely eliminated as part of the everyday tensions between communities and authorities.

In many instances of community violence the issue of resistance vs. acceptance was complicated. The police often intervened to protect certain people who were the victims of customarily sanctioned popular justice: for example, outsiders, informers, «bet welchers» and blacklegs. In these cases, and others, the contesting assertions of authority and justice become visible. A key aspect of the pacification of public spaces was the assertion of a state monopoly on the maintenance of public order. Community violence, in the form of mob attacks on deviants or private violent dispute settlement, often resisted state efforts by contesting local control of the streets and criminality. Local resistance arose from many concerns, among them the belief that legal punishment would not be sufficiently harsh. For their part, the police often intervened in local disputes, thereby denying the legitimacy of customary forms of violence and retribution and asserting the sole legitimacy of «official» violence in the public sphere. The nature of the negotiations between mentalities of violence and authority were not always heated. At times, the openness of the negotiation was striking: in 1857 a group of residents in Huddersfield asked the police for permission to customarily punish a local adulterer ${ }^{73}$. Resistance, violence and exclusion interacted in a context of competing powers. The process of «pacification» of public spaces was a highly complex affair, one that is obviously related to class, state power and attempts to impose hegemonic, «civilized» values. However, it is also necessary to appreciate that customary selfpolicing imposed and defended its own unequal social hierarchies and exclusions, thus complicating the issue of resistance to power.

The mixture of state coercion and the public's strategic acceptance of the police illustrates a shift in attitudes toward justice, authority and violence. "Official» channels were increasingly tolerated (and used) by an expanding segment of the population. Such a shift was closely connected to important cultural changes, in particular notions of respectability and new standards of masculine behavior that limited the legitimacy 
of interpersonal violence ${ }^{74}$. That legitimacy never disappeared, but it became more narrow and hemmed in by both state law and popular culture. This was founded on a policing of the self, an increasing self-control of violent impulses and urges. Connected, then, to institutional change was a cultural and psychological shift, what I refer to as the «civilizing bargain». That bargain - limitation on personal violence in exchange for the promise of pacified social spaces and the provision of official power to enforce them - was imposed (and accepted) in the nineteenth century. Here we can see the ways that the institutional, social, cultural and psychological aspects of the civilizing process worked together. The result was an alteration in violence mentalities and the social and state apparatuses for dealing with crime, dispute and social order. However, those changes were predicated on the maintenance of a successful alternative that increased individual security and provided reliable personal protection. Although the police were successful in establishing themselves as an accepted - even celebrated institution in British society, the nature of this arrangement has remained unstable.

\section{Conclusion}

The civilizing offensive that had begun in the eighteenth century and had increased its pace and reach in the nineteenth century attacked not only individual acts in an ad hoc manner, but it also confronted the cultural mentality that accepted relatively high levels of impulsivity, retribution, autonomy, and community control of cultural boundaries through violence. Customary violence had originated in a social context very different than late nineteenth-century England. As Thompson writes, «rough music», the most ritualized form of community violence, «belongs to a mode of life in which some part of the law belongs still to the community and is theirs to enforce», and highlights «modes of social self-control» that had broken down in the twentieth century ${ }^{75}$. However,

because law belongs to people, and is not alienated, or delegated, it is not thereby made necessarily more «nice» and tolerant, more cosy and folksy. It is only as nice and as tolerant as the prejudices and norms of the folk allow ${ }^{76}$.

This is an important point, and the foregoing should not be read as a call for legitimized vigilantism. However, what I hope I have pointed to are active and conflicted elements of the civilizing process itself. A civilizing offensive - at the same time institutional, cultural and social - sought to replace impulsivity and a diffuse legitimacy of violence with rational foresight and to conjure the self-controlled individual out of what was presumed to be a chaotic and brutal customary mentality. The state superseded autonomous neighborly violence with law courts and police, while the boundaries of acceptable interpersonal violence became narrower and the state assumed a monopoly on «legitimate» violence ${ }^{77}$. Extra-legal community violence became far less tolerated (for, as I have suggested, it had long been tolerated): the state considered it a threat to the social order, an affront the authority of the state and a throwback to a pre-enlightened era.

Deep cultural differences between the classes remained, but the cultural terrain had been altered by the closing decades of the nineteenth century. Although the reliability of statistical measures of crime has convincingly been challenged, it remains clear that violence (at least in the public sphere) became less prevalent over the course of the nineteenth century, signaling a number of shifts in British society ${ }^{78}$. New mentalities and vocabularies were emerging for the expression of class and cultural differences. 
The decline of custom was a gradual, partial, and far from linear progression. Workingclass communities could still pull together if they felt authorities interfered with their autonomy, as was increasingly the case as the state expanded its power to enforce school attendance or compulsory vaccination. In the 1890s, for example, authorities who tried to enforce compulsory vaccination were often set upon by enraged workingclass communities ${ }^{79}$. However, from the 1870 s onward, custom clearly faced a losing battle. Community self-policing, by and large, gave way to the policing of the self.

Nevertheless, the volatility in this bargain suggests that various elements within the civilizing process can work to contradictory ends: it appears that, at least at certain times, one aspect can imbalance another. The civilizing process's continuous reshaping of standards of behavior - and incessant refining of the subtle differences between behaviors - tends toward a constant redefinition of «violence». As much as the power of the state policing apparatus expands, it finds new social threats to the pacified public sphere: in effect, it «invents» new perceptions of violence ${ }^{80}$. This is not to say that violence is merely imagined, but rather to note that what constitutes «violence» changes according to new standards of behavior or the state's redefinition of law itself. At the same time, the state claims to wield a monopoly of violence in effectively dealing with the violence thus identified. The agencies of the state policing monopoly depend upon such claims for their own legitimacy. In the nineteenth century, traditional forms of order maintenance were exchanged for greater individual self-control; legitimate violence, and thus protection, was delegated to the state. However, as recent events suggest, the expectations of personal safety, pacified public spheres and state protection encouraged by the civilizing process can outrun the abilities of the institutions developed within that same historical movement. The delegated violence of the state can, at times, seem insufficient to the demands of maintaining expected standards of social peace. The resulting disjuncture in expectation and perception can lead to dissatisfaction with the "civilizing bargain» and a search for alternatives. Much of the historical work on the civilizing process has tended to look at the ways that its various components work together. The foregoing examination of institutionalized policing, and the «idea of policing» itself, highlights the potential for conflict within the civilizing process: the state's monopoly of violence is not something that simply exists, but rather a claim that, in order to function, needs to be maintained, accepted and seen to work.

\section{BIBLIOGRAPHY}

\section{Public Record Office manuscript sources:}

Assizes depositions from the Southeastern (Home) Circuit (ASSI 36).

Home Office papers, petitions for mercy, 1819-39 (HO 17).

Central Criminal Court, depositions, 1839- (CRIM 1). 


\section{Online sources}

BBC News, <http://news.bbc.co.uk>.

The Guardian, <http://www.guardian.co.uk>.

Stanko, E., Desperately seeking safety: problematising policing and protection, British criminology conferences, selected proceedings. Volume 1: emerging themes in criminology. Papers from the British criminology conference, Loughborough University, 18-21 July 1995, British Society of Criminology, published September 1998, accessed 15 March 2002, <http://www.lboro.ac.uk/departments/ss/ bsc/bccsp/vol01/VOL01_07.HTM>.

\section{Printed Sources}

Anonymous, Scenes from my Life, London, 1858.

Archer, J., The violence we have lost? Body counts, historians and interpersonal violence in England, Memoria y Civilización, 1999, 2, pp. 171-190.

Beattie, J., Crime and the Courts in England, 1660-1800, Princeton, 1986.

Caton, S., Anger be now thy song: the anthropology of an event, The Occasional Papers of the School of Social Science, Harvard University, paper no. 5, November 1999.

Cavanagh, T., Scotland Yard Past and Present: Experiences of 37 Years, London, 1893.

Certeau, M. de, The Practice of Everyday Life, Berkeley, 1984.

Chadwick, G., Bureaucratic Mercy: the Home Office and the Treatment of Capital Cases in Victorian England, diss., Rice University, 1989.

Cockburn, J., Patterns of violence in English society: homicide in Kent, 1560-1985, Past and Present, 1991, 130, pp. 70-106.

Cockburn, J., Punishment and brutalization in the English Enlightenment, Law and History Review, 1994, 12, pp. 155-179.

Conley, C., The Unwritten Law: Criminal Justice in Victorian Kent, New York, 1991.

Corbin, J., Insurrections in Spain: Casas Viejas 1933 and Madrid 1981, in Riches, D., (Ed.), The Anthropology of Violence, Oxford, 1986, pp. 28-49.

Davin, A., Growing up Poor: Home, School and Street in London, 1870-1914, London, 1996.

Davis, J., A poor man's system of justice: the London police courts in the second half of the nineteenth century, The Historical Journal, 1984, 27, 2, pp. 309-335.

Elias, N., The Civilizing Process: the History of Manners and State Formation and Civilization, Oxford, 1994.

Emsley, C., Crime and Society in England, 1750-1900, London, 1987.

Foucault, M., Discipline and Punish: The Birth of the Prison, New York, 1979.

Foucault, M., Power/knowledge: Selected Interviews and Other Writings, 1972-1977, New York, 1980.

Fuller, R., Recollections of a Detective, London, 1912.

Gaskell, P., Artisans and Machinery: The Moral and Physical Condition of the Manufacturing Population Considered with Reference to Mechanical Substitutes for Human Labour, London, 1836. 
Gatrell, V., Crime, authority and the policeman-state, in Thompson, F.M.L., (Ed.), The Cambridge Social History of Britain, 1750-1950, Cambridge, 1990, vol. 3, pp. 243-310.

Gatrell, V., The Hanging Tree: Execution and the English People, 1770-1868, Oxford, 1994.

Gay, P., The Cultivation of Hatred. The Bourgeois Experience, Victoria to Freud, vol. III, New York, 1993. Greenshields, M., An Economy of Violence in Early-Modern France: Crime and Justice in the Haute Auvergne, 1587-1664, University Park, 1994.

Hay, D., Snyder, F., Using the criminal law, 1750-1850: policing, private prosecution, and the state, in Hay, D., Snyder, F., (Eds.), Policing and Prosecution in Britain, 1750-1850, Oxford, 1989, pp. 36-47.

Heiny, H., Boxing in British Sporting Art, 1730-1824, diss., University of Oregon, 1987.

Hill, O., Homes of the London Poor: Four Years' Management of a London Court, London, 1883.

King, P., Punishing assault: the transformation of attitudes in the English courts, Journal of Interdisciplinary History, 1996, 27, 1, pp. 43-74.

Mayhew, H., London Labor and the London Poor, vol. II, New York, 1968.

Mearns, A., The Bitter Cry of Outcast London: An Inquiry into the Condition of the Abject Poor, London, 1883.

Miller, W., Police authority in London and New York City, 1830-1870, Journal of Social History, 1975, 8, pp. 81-101.

Paget, J., The London police courts, Blackwood's Edinburgh Magazine, 1875, 118, pp. 379-389.

Parliament, Local Reports on the Sanitary Condition of the Labouring Population of England, in Consequence of an Inquiry Directed to be Made by the Poor Law Commissioners, London, 1842.

Parliament, Reports to the Secretary of State for the Home Department on the State of the Law Relating to Brutal Assaults, \&c, London, 1875.

Philips, D., Crime and Authority in Victorian England: The Black Country, 1835-1860, Totowa, NJ, 1977.

Pile, S., Keith, M. (Eds.), Geographies of Resistance, London, 1997.

Price, R., British Society, 1680-1800: Dynamism, Containment and Change, Cambridge, 1999.

Riches, D., The phenomenon of violence, in Riches, D., (Ed.), The Anthropology of Violence, Oxford, 1986, p.1-27.

Ross, E., Survival networks: women's neighbourhood sharing in London before World War One, History Workshop, 1983, 15, pp. 4-27.

Ruff, J., Violence in Early-Modern Europe, 1500-1800, Cambridge, 2001.

Shipley, S., Tom Causer of Bermondsey: a boxer hero of the 1890s, History Workshop, 1983, 15, pp. 28-59.

Sindall, R., Street Violence in the Nineteenth Century: Media Panic or Real Danger?, New York, 1990. Spierenburg, P., Long-term trends in homicide: theoretical reflections and Dutch evidence, fifteenth to twentieth centuries, in Johnson, E., Monkkonen, E., (Eds.), The Civilization of Crime: Violent Crime in Town and Country since the Middle Ages, Chicago, 1996, pp. 63-105.

Storch, R., The plague of the blue locusts: police reform and popular resistance in northern England, 1840-57, International Review of Social History, 1975, 20, pp. 61-90. 
Storch, R., The policeman as domestic missionary: urban discipline and popular culture in northern England, 1850-1880, Journal of Social History, 1976, 9, pp. 481-509.

Storch, R., 'Please to remember the fifth of November': conflict, solidarity and public order in southern England, 1815-1900, in Storch, R. (Ed.), Popular Culture and Custom in Nineteenth-Century England,New York, 1982.

Swift, O., The Handbook of Boxing; Being a Complete Instructor in the Art of Self-Defence, London, 1840.

Taylor, D., The New Police in Nineteenth-Century England: Crime, Conflict and Control, Manchester, 1997.

Taylor, H., Rationing crime: the political economy of criminal statistics since the 1850s, Economic History Review, 1998, 51, 3, pp. 569-590.

Taylor, W., Moral economy of large towns: crime and punishment, Bentley's Miscellany, 1839, 6, pp. 476-482.

Thompson, E., Customs in Common, New York, 1991.

Walkowitz, J., Jack the Ripper and the myth of male violence, Feminist Studies, 1982, 8, 3, pp. 542-574.

Weber, M., Economy and Society: An Outline of Interpretive Sociology, Berkeley, 1978.

White, J., The Worst Street in North London: Campbell Bunk, Islington, between the Wars, London, 1986.

Wiener, M., The Victorian criminalization of men, in Spierenburg, P., (Ed.), Men and Violence: Gender, Honor and Rituals in Modern Europe and America, Columbus, OH, 1998, pp. 197-212.

Wood, J., 'The Shadow of our Refinement': Violence, Custom and the Civilizing Process in NineteenthCentury England, diss., University of Maryland at College Park, 2001.

Woods, D., Community violence, in Benson, J., (Ed.), The Working Class in England, 1875-1914, London, 1985, pp. 165-205.

\section{NOTES}

2. Although I have relied upon English primary sources, I have sought to tie my analysis to secondary scholarship reflecting a broader British perspective. I believe that my conclusions here are generally applicable to England, Wales and Scotland - thus my references throughout to «Britain» - while recognizing that their relevance to Ireland, with a somewhat different history of policing, is more problematic.

3. Stanko (1995).

4. «Families flee estate hate campaign», The Guardian, 10 August 2000.

5. «Hague's law: the whole truth and nothing but?» The Guardian, 27 April 2000; «Tories warn of rural vigilantes», BBC News <http://news.bbc.co.uk/hi/english/uk/newsid_724000/724702.stm>, 24 April 2000, accessed 15 March 2002. Martin's murder sentence was later reduced, on the ground of diminished responsibility, to manslaughter: «Shotgun farmer wins shorter jail term», The Guardian, 31 October 2001.

6. «Civilian wardens set to police streets», The Guardian, 5 December 2001.

7. I use the term «mentality» to refer to a collective store of cultural attitudes; akin to mental maps, mentalities interact with experience and organize the interaction between the individual and society. Cf., Corbin (1986, p. 29). 
8. On the "customary» mentality of violence more generally and its confrontation with nineteenth-century «civilizing» forces, see Wood (2001).

9. Weber (1978, p. 56).

10. Elias (1994, pp. 447-451).

11. Wood (2001, Chapter 2).

12. Spierenburg (1996, p. 71).

13. Cockburn (1994, p. 163).

14. W. Taylor (1839, p. 480).

15. Gatrell (1994, pp. 5, 326-341); Gay (1993); Price (1999, p. 8).

16. Greenshields (1994, p. 231).

17. $\operatorname{Ruff}(2001$, p. 73).

18. King (1996); Wiener (1998, pp. 203-204); Conley (1991).

19. Beattie (1986, pp. 36-40).

20. See a discussion of the trial format and popular justice in Foucault (1980, pp. 1-36). For examples: Cockburn (1994, p. 176) and Gatrell (1994, p. 93).

21. Greenshields (1994, p. 2).

22. See, e.g., ASSI 36/5 Kent Summer 1846, R. v. Price.

23. A second-hand boot seller in mid-century London reported that when he caught young thieves pilfering from his stock he took the matter into his own hands: «I've been robbed before, and I've caught young rips in the act. If it's boots or shoes they've tried to prig, I gives them a stirruping with whichever it is, and a kick, and lets them go» Mayhew (1968, II, p. 43). Mayhew observed, «Sometimes when these boys are caught pilfering, they are severely beaten, especially by the women, who are aided by the men, if the thief offers any formidable resistance, or struggles to return the blows», Mayhew (1968, II, p. 29).

24. Philips (1977, pp. 239-240).

25. Beattie (1986, p. 39); Chadwick (1989, p. 426).

26. Swift (1840,p. 6).

27. Shipley (1983); Heiny (1987); Wood (2001, Chapter 4).

28. On violence as a «resource», see Riches (1986, p. 13).

29. Times, 25 March 1828.

30. Mearns (1883, p. 19).

31. David Woods cites the case of a Dudley attendance officer who resigned from his post in 1876, because, «he found the work so rough, and met with so much insult and abuse that he couldn't stand it. He had been threatened three times in one day and if he was to do his duty his life was in danger. One man had said he would do three months Worcester (prison) for him, and another threatened to break his nose. In one district, a woman raised the whole neighbourhood against him» Woods (1985, p. 178).

32. During especially violent strikes, masters were sometimes themselves threatened with violence, one writer claiming that masters had to arm themselves and «by day, he had to use every precaution to avoid falling into the hands of an infuriated mob» Gaskell (1836, pp. 279-280).

33. Walkowitz (1982, p. 560).

34. Caton (1999, p 4).

35. Caton $(1999$, p. 4$)$.

36. Conley (1991, pp. 53-58).

37. Pile, Keith (1997, p. 16).

38. Fuller (1912, p. 210).

39. Central Criminal Court, CRIM 1/14/1, 1882. Depositions related to an assault upon Arthur Blatch.

40. See, e.g., ASSI 36/2 Cambridgeshire Summer 1833, R. v. Polley, et al. Polley and a companion were attacked at a pub and driven out of town. The source of the dispute is unclear. 
41. Storch (1976, p. 490).

42. Anonymous (1858, p. 35); Parliament (1842, p. 93).

43. Sindall (1990).

44. Elias (1994, pp. 447-454).

45. Davis (1984, pp. 314-415).

46. See D. Taylor (1997, pp. 1-10) for a cogent summary of «Whig» and «Revisionist» views of the period of the introduction of reformed police forces.

47. White (1986).

48. Cavanagh (1893, p. 27).

49. Conley (1991, p. 35).

50. For assaults on police committed in the contexts of rescues of people from police custody, see, e.g., HO 17/2 Ah 39 (1821); HO 17/2 Ah 48 (1828); HO 17/55 pt. 2, It 19 (1834); The Times, 25 March 1828.

51. HO 17/55 pt 2, It 19 (1834); HO 17/55 pt.1, Iv 1 (1835); HO 17/55 pt. 2, It 18 (1833).

52. D. Taylor (1997, Chapter 4).

53. Storch (1976, pp. 481-482).

54. See, e.g., HO 17/55 pt. 1, Iv1 (1835); HO 17/115 Wt 38 (1834); and Hill (1883, pp. 30-31).

55. Storch (1975); Gatrell (1990).

56. Gatrell (1994, p. 238).

57. Certeau (1984, p. 18).

58. Foucault (1979, p. 27).

59. Storch (1982); Conley (1991, pp. 35-37).

60. In 1820, a part-time constable, James Millman, was called out to suppress «riotous and disorderly Christmas singing» in Exeter. After repeated urgings from Millman, the crowd began to disperse. They did so, however, with «a great tumult». While Millman was attempting to take someone into custody, the crowd intervened and Millman struck a man with his «mace». Emphasizing the tenuous nature of police authority before the development of local constabularies, Millman was prosecuted by his intended target and convicted of assault. HO 17/2 Ah 39 (1821) James Millman.

61. E.g., ASSI 36/3 Norwich 1837 R. v. Tunmore, Singer, et al.; Conley (1991, pp. 38-41).

62. On this trend, see Hay, Snyder (1989).

63. All subsequent references to this case are from HO 17/115 Wt 38, William Bridges, London Sessions 1834 Assault.

64. Elias (1994, pp. 450-453).

65. Emsley (1987, pp. 145-146).

66. Paget (1875, p. 388).

67. Paget (1875, p. 388).

68. HO 17/55 pt.1, Iv 1 (1835); HO 17/55 pt. 2, It 19 (1834).

69. The Recorder of Abingdon, in his reply to a questionnaire from the Home Office, stated that «The only cases of violent assault with which the justices in session have to deal being assaults on policemen in the execution of their duty; in some cases, I am disposed to think, provoked by the indiscretion of the police themselves». Parliament (1875, p. 64).

70. Miller (1975, pp. 92-93).

71. Davin (1996, p. 37).

72. Ross (1983, p. 17).

73. Storch (1976, p. 500).

74. Wiener (1998).

75. Thompson (1991, p. 530).

76. Thompson (1991, p. 530).

77. Elias (1994, pp. 447-452). 
78. Archer (1999); H. Taylor (1998); Cockburn (1991).

79. Stroud Journal, November 24, 1893 (constables were «tossed like cockleshells» at an antivaccination auction); Keen's Bath Journal, February 29, 1890; National Anti-Compulsory Vaccination Reporter, vol. 5, 99, 102. I thank Nadja Durbach for these references.

80. Wood (2001, Chapter 2).

\section{ABSTRACTS}

In Britain, recent years have seen increasing criticism of police ineffectiveness, high-profile incidents of vigilantism and interest in alternatives to traditional policing. In light of these trends, this article first considers nineteenth-century community «self-policing», which ordered social relations according to a more diffuse distribution of acceptable violence. Second, it addresses the expansion of the state monopoly on violence and its accompanying expectation of more elaborate individual self-control, a «policing of the self.» Third, it suggests ways that the civilizing process can, in certain contexts, generate tensions if this «civilizing bargain»exchanging self-policing for state protection - fails to meet community expectations.

En Grande-Bretagne, dans les années récentes, on a vu monter la critique de l'inefficacité policière, les incidents d'auto-défense et l'intérêt pour des alternatives aux méthodes policières traditionnelles. À la lumière de ces tendances, cet article examine tout d'abord les modes de régulation interne aux communautés, qui hiérarchisaient les relations sociales en fonction d'une distribution plus diffuse de la violence acceptable. Il se penche ensuite sur le développement du monopole étatique de la violence et les attentes corrélatives à l'égard d'un contrôle de soi individuel plus élaboré, une "police de soi ». Enfin, l'article suggère de quelle manière le processus de civilisation peut, dans certains contextes particuliers, susciter des tensions lorsque cette «transaction civilisatrice » - entre la « police de soi » et la protection étatique - ne comble pas les attentes de la communauté.

\section{AUTHOR}

\section{J. CARTER WOOD}

Fleischstrasse 17, D-54290 Trier, Germany, jcarterwood@yahoo.com Ph.D. in modern British history completed at the University of Maryland, College Park in May 2001 under the direction of J.S. Cockburn. Current research interests: Mentalities of violence in Europe, 19th and 20th centuries. Dissertation: «'The Shadow of Our Refinement': Violence, Custom, and the Civilizing Process in Nineteenth-Century England», University of Maryland, College Park, USA (2001). 